\title{
6
}

\section{FRANKFURT ON THE STEPPE}

\begin{abstract}
Are you convinced then that Magnitogorsk is a city? A big city, even though much of it is still in wooden barracks? And that to build this city alone was no small problem? But - the city of Magnitogorsk is only incidental. It is, in essence, still mainly a construction camp, whose purpose is to erect the Magnitogorsk steel mill. This gives an idea of the magnitude of the steel mill that needs such a city to build it.
\end{abstract}

—Anna Louise STRONG (1931)

Through THE WINTER OF 1929, LIFE FOR THE GROWING POPUlation AT Magnitogorsk proceeded, albeit uncomfortably. Workers on site might have been aware that the important All-Union Design Competition to design their future quarters was taking place through reportage in the local newspaper Magnitogorsk Worker (Magnitogorskii rabochii), which began publication on January 1, 1930. They may also have guessed that the inconclusive results of the competition signaled an extension of makeshift housing conditions. ${ }^{1}$ As the English-language Moscow News reported almost two years later, the city was "in essence, still mainly a construction camp."

Despite the absence of comprehensive planning, Magnitogorsk continued to expand. The site held 40,000 people in September 1930. By December, the population stood at 60,000 residents, a number already well in excess of the competition brief's long-term maximum population of 50,000. By mid-1932, one contemporary account estimated that there were 200,000 people living on site in temporary barracks and dugouts. ${ }^{2}$ The designs submitted to the All-Union Open Design Competition for Magnitogorsk had concerned the construction of a conceptual apparatus for model socialist city-building. By any measure, Magnitogorsk met 
the demographic threshold of "city" by mid-1930, though it remained far from a model socialist one.

The postcompetition months involved the efforts of two designers, Sergei Chernyshev and Ernst May. Chernyshev, the Moscow architect whose previous plan for the city was maligned by Miliutin in 1929, returned to design Magnitogorsk in September 1930. German architect May, the former director of the Municipal Planning Department in Frankfurt am Main who oversaw the design and construction of 15,000 new housing units in that city, began development of a general plan and housing for Magnitogorsk a month later. Each architect was hired by a different client, and their projects overlapped and conflicted. A second competition between these two architects forced both clients and designers to engage in late-breaking, on-the-ground praxis.

Foreign architects who worked for the Soviet government during the first FiveYear Plan, like May, faced unprecedented economic, technological, and theoretical conditions that precluded direct importation of architectural and planning models from the West. Over the period of their consultancy, from 1930 to 1933, the building typologies (and resolve) imported from Germany by May and his architectural brigade were bent to the particulars of Soviet conditions, as the narrative of their design work for the city of Magnitogorsk reveals. An experimental urban block known as the Kirov District remains in Magnitogorsk as material testament to that architectural exchange.

\section{Shifting Priorities}

A seismic shift in Soviet sociospatial theory was already underway in the months following the Magnitogorsk competition. Newspaper columns devoted to the socialist city debate had petered out by mid-1930, and on May 16, the Central Committee of the Communist Party (Vsesoiuznaia kommunisticheskaia partiia bol'shevikov or $\mathrm{VKPb}$ ) issued a "Resolution on the work to restructure byt," that unequivocally communicated the Soviet leadership's position that the socialist urbanism debate was over. The resolution opened with critique, noting that "along with the growth of a movement toward a socialist byt, extremely unreasonable semi-fantastic schemes exist. It is therefore extremely harmful to individual comrades (Yu. Larin, Sabsovich, et al.) to attempt in 'one jump' to clear those obstacles to the socialist reconstruction of byt which are rooted . . . in the country's economic and cultural backwardness." Sabsovich was reproached by name-he was on the outs. His proposals for swift and total refashioning of daily life were suddenly deemed "semi-fantastic," and unsupportable by the USSR's most powerful political executives. 
Economic realities explain the Central Committee's change of tune. As the price tag for heavy industry construction escalated, "soft" construction projects like housing, communal services, and cultural and recreational facilities slipped down the State's list of priorities, as the resolution made clear:

We need to focus maximum resources on the rapid industrialization of the country at this moment, which creates real material preconditions for a radical remaking of byt. Projects to redevelop existing cities and construct new ones [that] have appeared recently in the press . . . are intended to be funded exclusively by the state, with immediate and complete socialization of all aspects of the working people's byt: food, housing, education of children with separation from their parents, elimination of domestic bonds between family members, an administrative ban on cooking, and so on. The implementation of these harmful, utopian undertakings, which do not consider the material resources of the country and the degree of preparedness of the population, would lead to an enormous waste of resources and a brutal discrediting of the idea of the socialist transformation of $b y t$ altogether. ${ }^{3}$

The Central Committee's resolution dispensed with vision, and instead stressed the paucity of state resources and the intractability of the populace. If the first Five-Year Plan was to meet its stated targets, state resources would be funneled to heavy industry, full stop. Complete socialization of byt was impossible-the economics did not work. Even more problematic than funding shortfall, the resolution claimed, was theoretical overextension. The "utopian" schemes of Sabsovich did not take into account the "preparedness of the population," which is another way of saying that these schemes ignored the transitional nature of Soviet society. Nadezhda Krupskaia, who had waged a similar critique in the previous months, was vindicated.

The remainder of the resolution was a list of action items that confirmed the closure of the debate. The Central Committee gave the Sovnarkom fifteen days to develop rules for the construction of workers' settlements and residential buildings in newly built and existing cities and towns. These guidelines, which echo design instructions in the Magnitogorsk competition brief in many ways, include accommodation for some communal services to support the transition to a socialist byt. The Central Committee stipulated that new workers' settlements at large enterprises (like Stalingradstroi, Dniprostroi, Magnitostroi, Cheliabstroi) would be separated from the industrial zone by a sufficiently wide green axis, and that roads, means of communication, and municipal infrastructure like water, electricity, canteens, clubs, schools, and medical care must be provided. Maximum hygiene and convenience would be ensured, and measures taken to reduce the price of construction. The resolution also sought to stave off administrative dysfunction. All party organizations were instructed to ensure "maximum resource mobilization" for 
residential construction, and trade union organizations were tasked "to take urgent measures to streamline and strengthen the financial restructuring of byt." 4 Lastly, the Central Committee proposed that Vesenkha immediately expand production of equipment for factory-kitchens, mechanized laundries, and so on, and consider increasing funding for byt-restructuring projects in the coming year.

Although ostensibly a resolution to support the restructuring of byt, the document reads as censure. After months of vigorous and wide-ranging discussions, the Central Committee intervened in the socialist urban debate to prohibit radical changes to the everyday life of workers and make clear that funding for the expensive undertaking was not forthcoming. What did this mean for Magnitogorsk? Just three days after Pravda published the resolution, 14,000 workers laid the foundation for the first blast furnace for the Magnitogorsk Iron and Steel Works. ${ }^{5}$ The construction of the factory was underway, the first Five-Year Plan clock was ticking, and a city-visionary or not—-still did not exist. The time had come to call in experienced planning experts who would blinker themselves to the chaos surrounding the socialist urbanism debate and simply produce housing.

\section{German Housing: Standardization, Economization, and Efficiency}

Back in the fall of 1927, a delegation of Soviet officials engaged in solving the housing crisis embarked on a month-long business trip to tour new worker housing settlements (siedlungen) in Germany. ${ }^{6}$ Representatives from both Azneft and the Azerbaijani Vesenkha were among the group, traveling westward to see the fruits of German industrial housing construction at the same time Aleksandr Ivanitskii was completing the 1927 Baku Plan in his Moscow office. Thanks to Ivanitskii, Azneft representatives were uniquely positioned to advocate for architectural standardization. Less than two years before, hundreds of oil worker housing units were built in record time using a limited number of types in the garden-settlement of Stepan Razin. This mid-1920s success in Baku was an outlier in the Soviet sphere, however. The Germans were irrefutably ahead in the housing game in terms of quality and quantity of housing units produced thanks to industrialized construction techniques. Soviet housing officials on the 1927 tour were especially interested in how the Germans mass produced large architectural elements like pumice stone slabs and shipped them to building sites that were prepped to receive them. The report from the tour noted that "thanks to such slabs, construction [of the twentyfive-unit houses at Frankfurt am Main's Praunheim siedlung] takes just seventeen days and requires very few workers to complete." 7 The delegates concluded that in a command economy like the Soviet Union, architectural standardization would have an even greater reach and impact than in Germany. The group also toured the "Die Wohnung" Housing Exhibition (better known as the Weißenhofsiedlung) in Stuttgart, a full-scale experiment for prefabricated modern housing types. The Soviet 
delegation was photographed in front of architect Max Taut's round-edged housing prototype and Josef Frank's duplex, with Mies van der Rohe's multiunit apartment building in the deep background (figure 6.1).

The fact that many of the German settlements they toured were built under socialist administrations made the architectural ideas, forms, and techniques easier for Soviet officials to justify transferring. In Berlin-Britz, the delegation toured the Hufeisen Siedlung (1925-33), the so-called horseshoe settlement, designed by architects Bruno Taut and Martin Wagner. The project, still under construction during their visit, was developed by the "Gehag," Germany's largest building cooperative funded largely by socialist trade unions and run by a majority socialist administration. Walter Gropius's Siedlung Törten (1927), also visited, was built with the support of a Democratic Party mayor and Socialist Party officials of the city of Dessau. ${ }^{8}$ Gropius gave the group a personal tour of Törten, the Bauhaus, and his private house. Members of the Soviet delegation were notably starstruck in the presence of the Bauhaus director, who was "well known to Soviet builders as an innovator-architect." 9

The Soviet housing experts reserved their most effusive praise for the projects built in Frankfurt am Main under mayor Ludwig Landmann (a Democrat supported

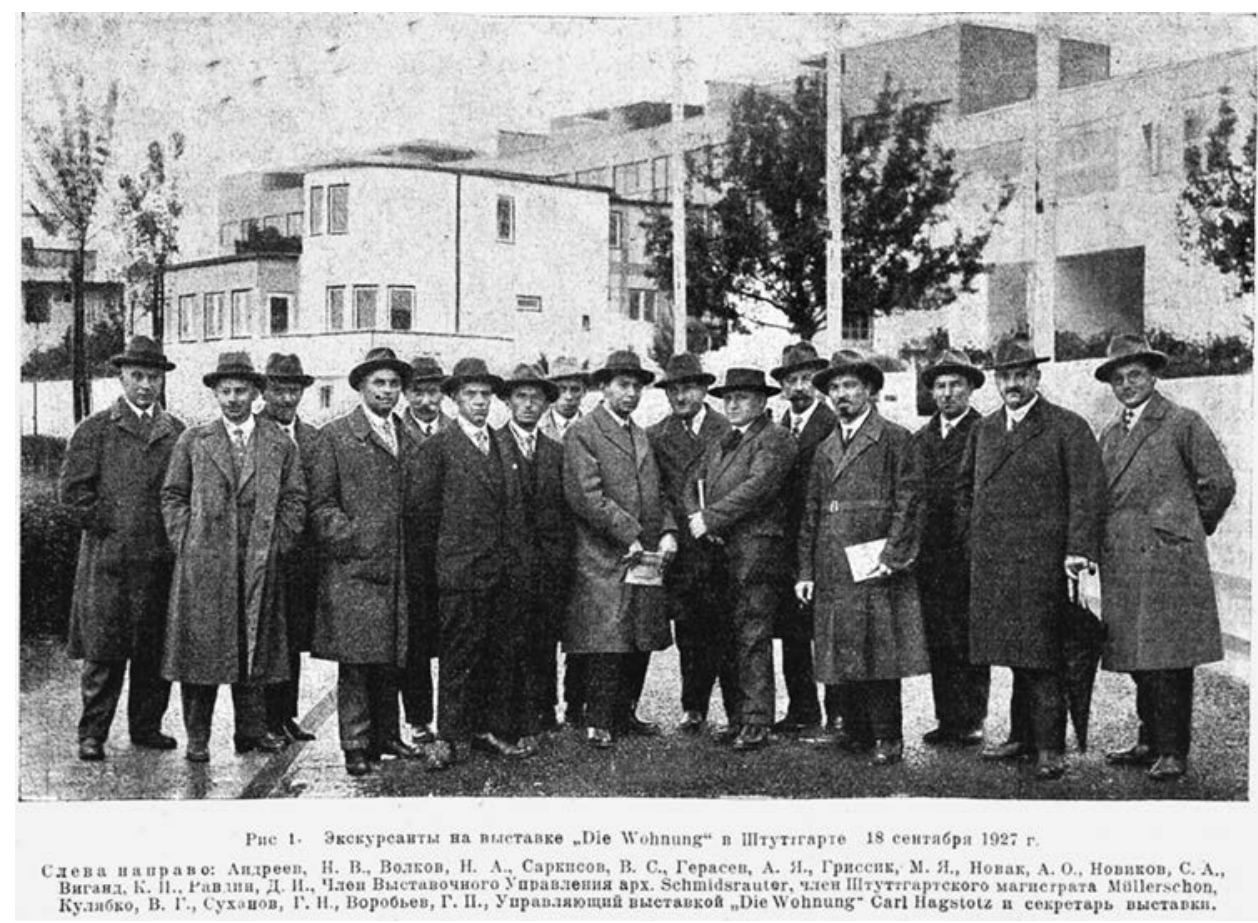

Figure 6.1. Excursion of Soviet housing experts to the "Die Wohnung" Housing Exhibition (Weißenhofsiedlung). Stuttgart, Germany, September 18, 1927. S. N. Nakhmanson et al., Sovremennoe stroitel'stvo Germanii: Pervaia zagranichnaia ekskursiia inzhenirov-stroitelei i arkhitektorov (Moscow: Gostekhizdat, 1929), 10. 
by the Socialist Party) and his chosen architect-planner, May. Landmann was a politician deeply invested in large-scale planning. In 1917, as an assemblyman, he advocated establishing a housing department in Frankfurt that would address "in a uniform way all questions of urban planning having regard for economic, legal, cultural, and artistic aspects within the framework of a major program." ${ }^{10}$ When he became mayor of the city in 1924, he hired May to lead this comprehensive physicaleconomic-social planning effort. Landmann granted May extraordinary powers in the position of Frankfurt's Director of Municipal Planning from 1924 to 1930. In this period May created a general plan for the city that checked unruly growth and charted out future interventions; directed all municipal building projects; oversaw design of all new public housing; ran the city's largest building society; supervised building code officials; and adjudicated all applications for municipal and federal building loans. ${ }^{11}$ May exerted such complete control over Frankfurt's built environment during his tenure that he was, effectively, overseer of a total planning effort on the municipal scale. His absolute administrative power did not translate to fiscal profligacy, however. From 1925 to 1928, May's office was the broker for approximately 26 million marks per year for settlement design and construction. ${ }^{12}$ This fixed budget functioned similarly to early Soviet control figures, keeping expenditures for capital construction on a flat line and encouraging economization. Denser site planning, more efficient construction techniques, and ascetic architectural detailing yielded more housing units with the allotted funding. Increasingly, May's office practiced spatial economization within the unit designs as well, to build apartments that the workers could afford in a depressed economy. Between 1926 and 1929, the average new four-room apartment built in Frankfurt am Main shrank from ninety-four to seventy-five square meters. ${ }^{13}$ Once his siedlungen were underway and deemed a success May went on a promotional speaking tour that included a lecture titled: "Oh! If I were in charge of town planning with an unlimited budget!!" 14 The lecture both highlighted his finished projects' frugality and imagined a future in which such penny-pinching would not be necessary.

May's work tacked between "establishment” planning and avant-garde architecture. He is like Ivanitskii and Pavel Aleshin (the architect featured in the Kharkiv story to come), a figure who defies easy categorization. According to Corinne Jaquand, May was the only active member of both IFHTP (The International Federation for Housing and Planning, founded in 1913 by the garden city theorist, Ebenezer Howard) and CIAM (Congrès Internationaux d'Architecture Moderne, the International Congresses of Modern Architecture, founded in 1928 by Le Corbusier, Sigfried Giedion, and others), two organizations that rarely saw eye to eye aesthetically or ideologically. ${ }^{15}$ May's investment in the garden city movement stems from his 1910 apprenticeship to Raymond Unwin, whom he assisted with designs for Hampstead Garden Suburb, a satellite town north of London. Two particular recommendations from Town Planning in Practice, Unwin's book that May helped to translate into German in 1910, were taken by May into his Frankfurt 
projects: decentralization and cooperative service provision. ${ }^{16}$ First, May located his new settlements outside of the city center in his plan for Frankfurt am Main, mobilizing the foundational garden city principle of decentralization in the industrial age. Second, May sought to install Unwin's neighborhood unit, a block that offers shared services in addition to residential programming. Unwin had written that it was possible, "and indeed easy, by co-operation to provide for all a reasonable share of these same conveniences and luxuries" like common rooms, baths, washhouses, recreation and reading rooms, and eventually common kitchens and dining halls. ${ }^{17}$ In the planning stages for New Frankfurt, May followed Unwin's lead, setting aside land for robust community services in each siedlung. In the end, the Bruchfeldstrasse siedlung was the only settlement with a full-fledged community center akin to the Soviet workers' club, but Praunheim boasted an auditorium, club offices, and a branch library. ${ }^{18}$ Much to May's disappointment, the New Frankfurt program for nurseries, daycare centers, and kindergartens in each siedlung was scrapped for lack of funding. ${ }^{19}$

Siting and programming commonalities aside, the spare architectural language of May's New Frankfurt housing had little in common with Hampstead's Arts and Crafts pitched-roofed bungalows. The largely orthogonal, flat-roofed, white-bodied multiunit housing complexes built under May's direction addressed functional needs and rejected historical allusions as a matter of principle, as he explained:

The external form of the Frankfurt Siedlungen is developed from the situation of the internal structures and dispenses with representative gestures and decorative elements, both old and new. [We take] an approach to building that no longer sees the ultimate fulfilment of architectural aesthetics as lying in the so-called beautiful facade with a symmetrical composition animated by piers, cornices, and ornaments ... By the repetition of numerous, similar elements and by harmoniously adapting the buildings to the landscape, [we] strive for architectural and urban design effects that are derived from our times. ${ }^{20}$

The goal for New Frankfurt's designers under May was no less than to channel the Weimar zeitgeist architecturally, permitting the appearance of the settlements' buildings to arise from the marriage of sensitive siting, functionality, and industrialized building methods. Unlike the jurors of the Magnitogorsk competition, May was unconcerned about architectural standardization's experiential monotony. "We are of the opinion," he explained in a 1929 lecture, "that the collective element in the life of people today, which so strongly influences work, sport, and politics, must logically be reflected in their housing . . . the Siedlung of our times will, like the honeycomb, be defined as the sum of similar housing elements." ${ }^{21}$ May celebrated uniformity of architectural appearance as a means to dissolve corrosive individuality and encourage collectivity. 
Two of the Frankfurt am Main settlements the Soviet housing delegation visited in 1927 were Praunheim and Westhausen (1925-29), located in the suburban Nidda Valley. In his general plan for Frankfurt, May pushed through zoning that designated previously unproductive swamp land for agricultural use, thereby reserving a perpetual green belt between the expanding urban center and his new settlements. ${ }^{22}$ Praunheim was the first project built using the Frankfurter Montageverfabren (Frankfurt Assembly Method or, colloquially, the "May system"), in which prefabricated structural panels were tilted or hoisted up on the construction site. In the first phase at Praunheim, long rows of attached single family three-story houses were built along the east-west axis, following the preexisting roads that encompassed the site. In Westhausen, May and his staff experimented with a highly regimented site plan with a low-rise multifamily housing bar, or zeilenbau, arranged in parallel rows aligned on the north-south axis to maximize insolation along the broad east-west facades (figure 6.2). ${ }^{23}$ Distance between the rows was determined by shadow studies, and each rowhouse was entered on the east side, with the west reserved for garden plots. ${ }^{24}$ Because the zeilenbau projects were superblocks like the Armenikend test block in Baku, the Azerbaijani delegates would have recognized the cost-saving benefits of the pedestrian-friendly site planning strategy, namely economization on the hard infrastructure of roads and streetlights. Upon conclusion of their tour, the Soviet delegation enumerated four aspects of May's Frankfurt settlements that they proposed to emulate and turn into policy. Housing should be produced by "factory" rather than "handicraft" methods, meaning that construction elements should be prefabricated, shipped in, and installed on site, leading to

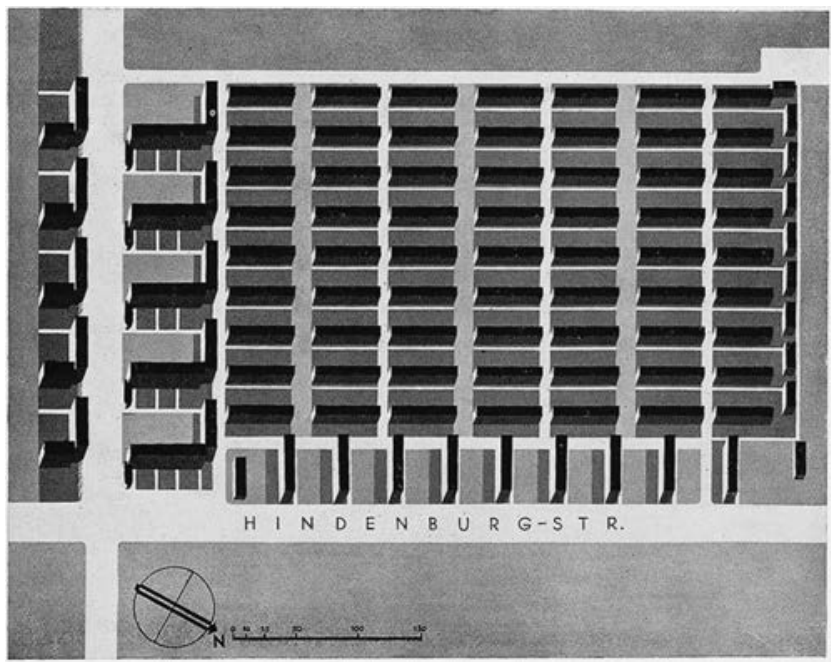

\section{SIEDLUNG WESTHAUSEN}

Anzahl der Wohnungen: 1532 Bauherr: Gartenftadt A. G. und Naffauifche Heimftătte

Gefamtplan: E. May, Mitarbeiter H. Boehm und Bangert

Architektonifche Bearbeitung: E. May, E. Kauf mann, F. Kramer, Blanck, fowie die Privatarchitekten O. Fucker, F. Schufter.

Figure 6.2. Siedlung Westhausen site plan, Frankfurt, Germany, 1929. Low-rise multifamily housing bars, zeilenbauen, sit in parallel rows aligned on the north-south axis to maximize insolation on the east-west facades. Planners: Ernst May et al. "Funf jahre wohnungsbautatigkeit in Frankfurt am Main," Das Neue Frankfurt, no. 2/3 (1930): 56. 
a 30 percent reduction in project costs. Construction should be conducted yearround. Drawing sets should consist of both standardized designs and installation instructions, "similar to the drawings used for assembling cars." Finally, the whole project delivery system at all levels should be carefully organized and monitored to reduce construction costs. ${ }^{25}$

On May's recommendation, New Frankfurt was the site and focus of the second meeting of CIAM in 1929, which took as its theme Existenzminimum (the minimum subsistence dwelling). The two official Soviet delegates to the congress were Moisei Ginzburg and Nikolai Kolli, both members of OSA who knew Le Corbusier from his travels to the USSR beginning in $1928 .{ }^{26}$ The journal Das Neue Frankfurt reported that another Soviet guest at the congress was the engineer German Krasin, at the time the chairman of the Commission for Housing Construction at the Central Scientific Research Institute of Building Construction (Gosudarstvennyi institut sooruzhenii or GIS), an organization under the umbrella of Vesenkha. ${ }^{27} \mathrm{Krasin}$ was later on the expert panel that selected May as the planner for Magnitogorsk, and he worked closely with May's design team in his role as head of the governmental commission on Magnitogorsk.

CIAM2 opened on October 24, 1929, the inauspicious date of the Wall Street stock market crash. Delegates and the public listened to lectures and debates, toured the New Frankfurt housing settlements, and visited the congress exhibition. Other active members of CIAM, like Walter Gropius, sought to maintain broad discussion of the theme, but the congress was undeniably a publicity juggernaut for May's New Frankfurt. “The Minimum Dwelling Unit" exhibition that opened at the end of the congress featured an international collection of 207 spatially economized housing floor plans, but the majority were German examples, and half of those were designed under May's supervision for Frankfurt. ${ }^{28}$ Catherine Bauer, whose Modern Housing (1934) would introduce European housing innovations to a US audience, noted that the air of excitement at the conference was due in large part to the fact that May had one foot out the door. He was packed and ready to depart for a lecture tour in Leningrad. ${ }^{29}$

\section{Ernst May, Soviet Planner}

In March 1930, Tsekombank, the Central Bank for Municipal Economy and Housing, was named state financier for the construction of all socialist cities. Although thirty-eight cities were officially designated for construction during the first FiveYear Plan, once tabula rasa sites and interventions in existing cities were added up, the number of urban scale construction projects undertaken during the plan was more like $150-170 .{ }^{30}$ Each project was run by a different constellation of administrators and designers, leading to mixed results. In an effort to install a measure of 
quality control, Tsekombank placed advertisements in Union-wide newspapers and journals, soliciting assistance from experienced architects for an in-house design office, an outreach that purportedly received little return. ${ }^{31}$ As Evgeniia Konysheva and Mark Meerovich note, the decision of Tsekombank and other Soviet organizations to turn to foreign specialists in the early 1930s cannot be wholly explained by a shortage of local design talent. According to contemporary Soviet sources, in 1928-29 there were approximately 10,000 architects and civil engineers working in Moscow, another 9,000 in forty different design offices in Leningrad, and 5,500 in Kharkiv. ${ }^{32}$ What foreign architects like May or Albert Kahn had to offer was cutting-edge expertise with architectural standardization.

May was invited back to the USSR in early 1930 to deliver lectures in Moscow, Leningrad, and Kharkiv that drew on his Frankfurt experience. Timely topics included “The New City," “The State of Residential Building in Germany," and “The Rationalization of Residential Construction." Upon request, May prepared an additional lecture for a select group of Soviet specialists entitled, "Organizational Proposals Concerning Russian City Planning and Residential Policies." 33 This lecture appears to have been an opportunity to vet the architect, and by all accounts May passed muster. Soon after this visit E. Luganovskii, the head of Tsekombank, traveled to Frankfurt am Main to hire May and his architectural brigade. ${ }^{34}$ In a letter dated June 15, 1930, Tsekombank contracted May as its head design consultant for a period of five years. In this capacity May would 1) draft plans for new cities and settlements and replan old ones; 2) rationalize and standardize construction of residential buildings and civic structures and improve methods for construction of cities and settlements; 3 ) develop typical projects for residential buildings and civic buildings; and 4) develop projects for factories to produce standardized residential buildings. ${ }^{35}$ May did not explicitly sign on with the Soviets to plan Magnitogorsk. Under his agreement with Tsekombank, May was responsible for urban design, housing typology design, and systems design throughout Soviet territories. He had ample experience with all three tasks, but the latter two, having to do with standardization, were of greatest interest to Tsekombank. At the start of 1929, Tsekombank had published-with parallel Russian and German texts-Projects for Workers' Dwellings (Proekty rabochikh zhilishch), an album of high-quality housing unit designs compiled from various Soviet projects. In the book's preface, Luganovskii lamented that "one of the main drawbacks of [Soviet housing] construction is that the design of residential buildings is inexpedient and extremely heterogeneous in nature and approach." ${ }^{36}$ Type design, forwarded by the Tsekombank album and employed in May's work in Frankfurt, assumes replication. A single, well-resolved housing type could be tested and then deployed throughout Soviet space, saving time and money. In addition to developing standardized building types, May and his team would develop design and construction methods to rationalize the ragtag Soviet building industry and would design factories for manufacturing standardized 
building components. May signed the contract, agreed on an October departure date from Germany to the USSR, and went about gathering his brigade of experienced designers. ${ }^{37}$

It was not difficult to entice architects to leave Germany in the year after the international economic collapse. According to artist-architect Erich Borchert, "two years ago [in 1928], in the office of one of Berlin's best architects, there were 85 architects and specialists-now there are only 5." ${ }^{38}$ In the lead up to his departure, May presented himself to the German press as a specialist-mercenary rather than a fellow traveler. "I am not interested in politics," he told the architectural journal Bauwelt. "I am a German architect fulfilling a contract with the Russian government in the hope of helping the German economy a little at the same time." ${ }^{39}$ He even spun the consultancy as an opportunity to advance the international field of urban planning-again, without mention of politics. "Until now my activities, like those of almost all town planners in Western countries, has consisted largely of urban expansion, albeit on the new basis of satellite theory; but now I am to develop plans for new towns which are to be created from nothing as independent organisms." 40 Like his high-ranking clients plotting the Union's future from maps in Moscow, May ascribed to the tabula rasa myth of Soviet territorial expansion. Unlike many of his clients, however, he and his brigade would soon experience in person the contextual realities of those remote sites.

Meanwhile, the administration of Magnitostroi-without consulting its funder, Tsekombank-handed the general planning project over to the State Institute for City Planning for the Russian Republic (Rossiiskii institut gradostroitel'stva i intensivonnogo razvitiia or Giprogor) under the leadership of Chernyshev. ${ }^{41}$ Despite intense pressure to complete the plan, the Giprogor team was plagued by delay. A month into the renewed design effort Chernyshev reported to the Communist Academy, citing a litany of reasons for his team's lack of progress. The factory production targets kept changing, which resulted in fluctuating territorial spread. Shifting decisions about the purifying-cleansing ponds and the location of the processing factory made spatial planning impossible. The population targets for the city were subject to constant change. The administration refused to resolve the size of the sanitary zone between the factory and the workers' settlement. Finally, as Ivanitskii had noted in Baku, the ambiguous general line on the planning and architecture of the ideal socialist city hindered real-time progress. By the fall of 1930, the planning and housing situation in Magnitogorsk was "catastrophic" and was even threatening the timely startup of the factory. Tsekombank decided it was time to intervene (or "meddle"-vmeshivat'sia) in the situation and called in May. ${ }^{42}$

\section{Travel to Magnitogorsk}

In October 1930, May left Berlin for Moscow with seventeen colleagues to begin his comprehensive design consultancy with the Soviet government. ${ }^{43}$ Soon after they 
arrived in Moscow they were instructed, with just twenty-four hours' notice, of their departure for the Urals where they would act as planning consultants for the socialist city of Magnitogorsk. ${ }^{44}$ Tsekombank representatives accompanied the May Brigade on their four-and-a-half-day train trip. ${ }^{45}$ May had ample time traveling through the western Russian landscape to jot down observations that invariably tamed unfamiliar conditions. He noted that the peaks of the Urals recalled the Rhön Mountains and that the train coach outfitted for the foreign specialists was filled with the "special kind of good humor that often fills the long hours of wait in a dugout or the long evenings in an alpine ski hut." 46 The further the architects traveled from Moscow the more difficult analogical observations became. By the time May crossed the Ural Mountains and left behind Cheliabinsk, the capital of the Ural region, the unprecedented nature of this new context sank in. "We could immediately see by the faces of the native population that here was a different ethnic group. Their slanted eyes revealed that we were now dealing with Mongols ... We did not see many villages," he wrote, "but flocks of horses of all colors roamed freely across the frozen soil." 47

On November 2, 1930, May and his team reached the location for the future city of Magnitogorsk. May recalled his first view of the site:

We reached our destination on a temporary rail spur. Fog gave way to clear skies, and our eyes beheld a fascinating spectacle. From the middle of the steppe arose a number of flat hills and among these, of larger size-a mountain of iron ore. One hundred and fifty million tons of rich iron-ore deposits are located in this area, ready to be surface mined. In order to exploit these deposits, the second largest industrial complex in the world has been planned here as part of the great Soviet plan of industrialization . . Now 40,000 workers, living in temporary barracks, apply their labor to one the mightiest industrial ventures of our time. The innumerable blinking lights of the labor camp and the bright floodlights used for night work made an unforgettable impression on our minds. ${ }^{48}$

Though May's text amplifies the drama of this first encounter, his basic description matches other contemporary reports of the site. The architect finally stood on the steppe, took in the topography, and grasped the material implications of, and limitations on, the planning task. Chernyshev, who was already well acquainted with the site, had arrived in Magnitogorsk with his Giprogor design team a day before the Tsekombank-May group.

On the day of May's arrival, the two design teams met with local officials at the offices of Magnitostroi. The architects were presented with an exhaustive list of thirty-six items to consider when designing the city. Like the Magnitogorsk competition brief from which it undoubtedly was generated, this list encompassed all scales of urban intervention from regional infrastructure down to targeted living norms. The requirements foreclosed fantastical proposals like those submitted by 
the OSA and Stroikom competition teams. As in the brief, the average height of buildings in Magnitogorsk was to be four to five stories (no high-rises), and smallscale construction was discouraged (no izbas on chicken legs). Most surprisingly, however, the architects were instructed that "apartments for individual living [individual'nogo zhil'ia] will be constructed with two to three rooms, with a small percentage (no more than 5 percent) with four rooms." ${ }^{49}$ Dormitories were requested but included as an afterthought, and the percentage of collective housing types was left to Magnitostroi and the local branch of Gosplan to determine. The typical residential commune, the fundamental building block of the All-Union competition, and the linchpin for sociospatial change in the 1929 urbanism debates, had disappeared altogether in keeping with the high-level ideological shift away from a radical reconfiguration of byt.

The May Brigade toured Magnitogorsk in Ford motorcars, met the Soviet, US, and German engineers in charge of factory construction, and collected information for four days. It was clear to the team from the outset that the site had serious contextual limitations. They concluded that "it was simply impossible to devise a solution based purely on desired relationships between industry and housing." 50 Hemmed in by the expanding production area to the north, and the river and topography to the west and south, a residential area would have to be wedged into the southeast. This was the area where, in the summer months before May's visit, residential foundations had already been laid. A photograph of the first foundation pit excavation provides a glimpse of the conditions May and his team likely witnessed that November (figure 6.3). With nothing but a horse, a pile of foundation stones, and the waving grass of the steppe in the background, workers (and one specialist in a suit) look down expectantly into the hand dug trench. May later lamented these buildings' existence specifically. "We were bound in our work by the fact that one of the project organizations designed a complex of 16 four-story buildings before our arrival. In parts the buildings' foundations had been laid, and in another the roofs were already in place . . Numerous organizations working at increasingly accelerated rates were creating temporary or permanent buildings which were later a serious obstacle to crafting a clean plan of the city." ${ }^{51}$ During their first visit May's team also saw that the vast majority of Magnitogorsk's 40,000 residents resided in the rows of wooden barracks between the factory site and the river (figure 6.4). The single men, women, and families slept alongside one another in beds lined on both sides of the open plan and ate together in common canteens (figure 6.5). The forced communality that had been written into the Magnitogorsk competition brief was already a condition of life on site. 


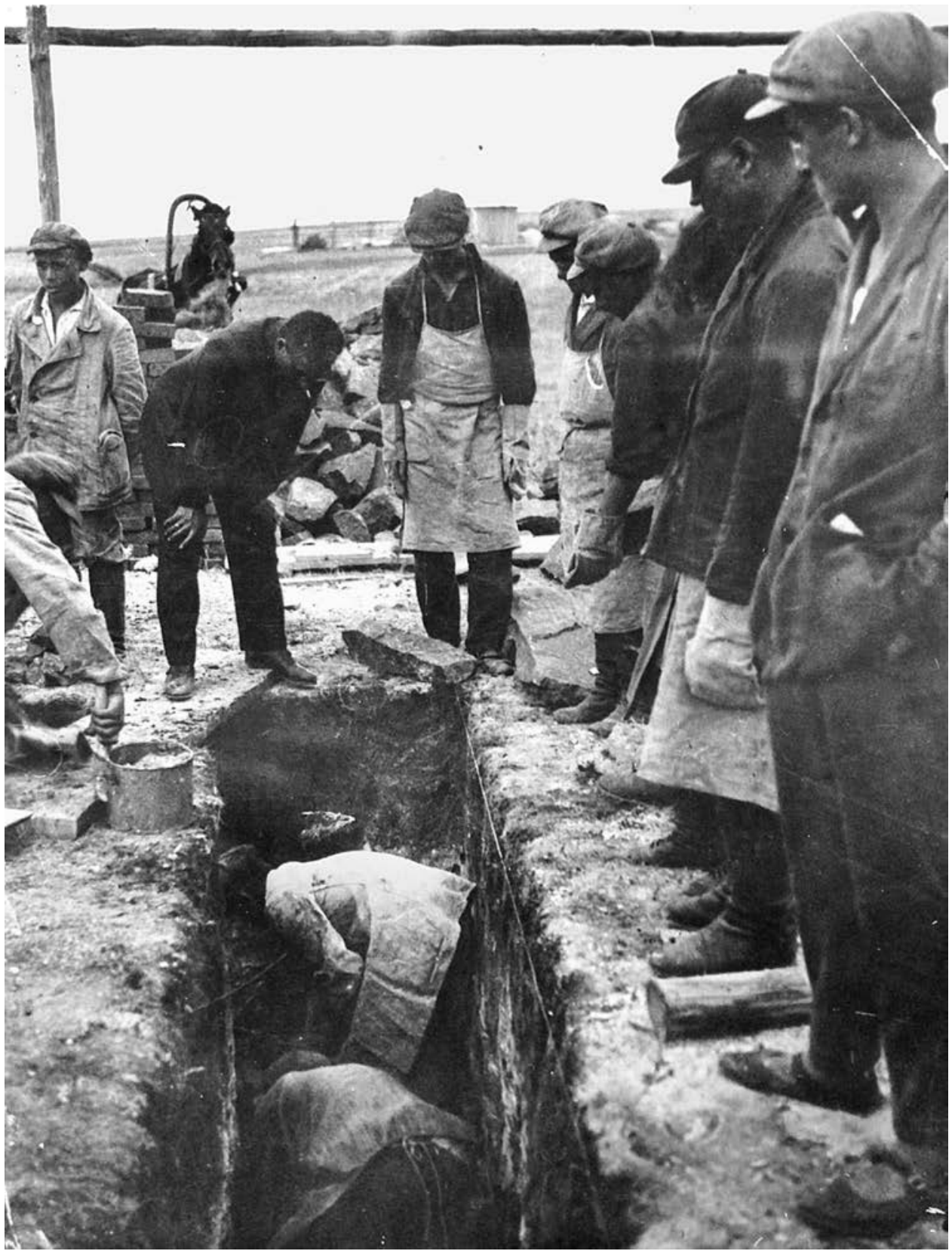

Figure 6.3. Laying the first housing foundation, Pionerskaia Street, Magnitogorsk, Russia, summer 1930. Magnitogorskii kraevedcheskii muzei. 


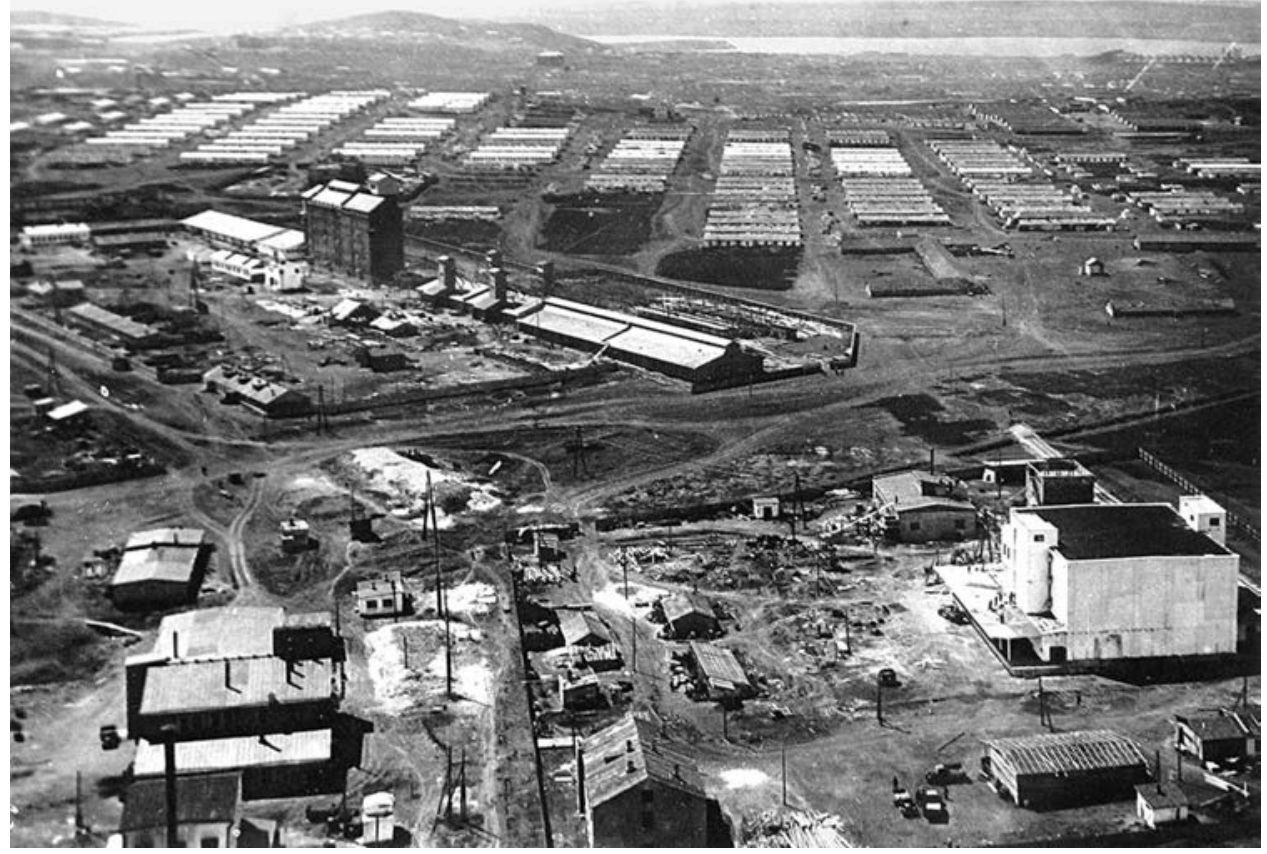

Figure 6.4. Aerial view of factory construction with rows of wooden barracks in the distance, Magnitogorsk, Russia, c. 1930. Magnitogorskii kraevedcheskii muzei.

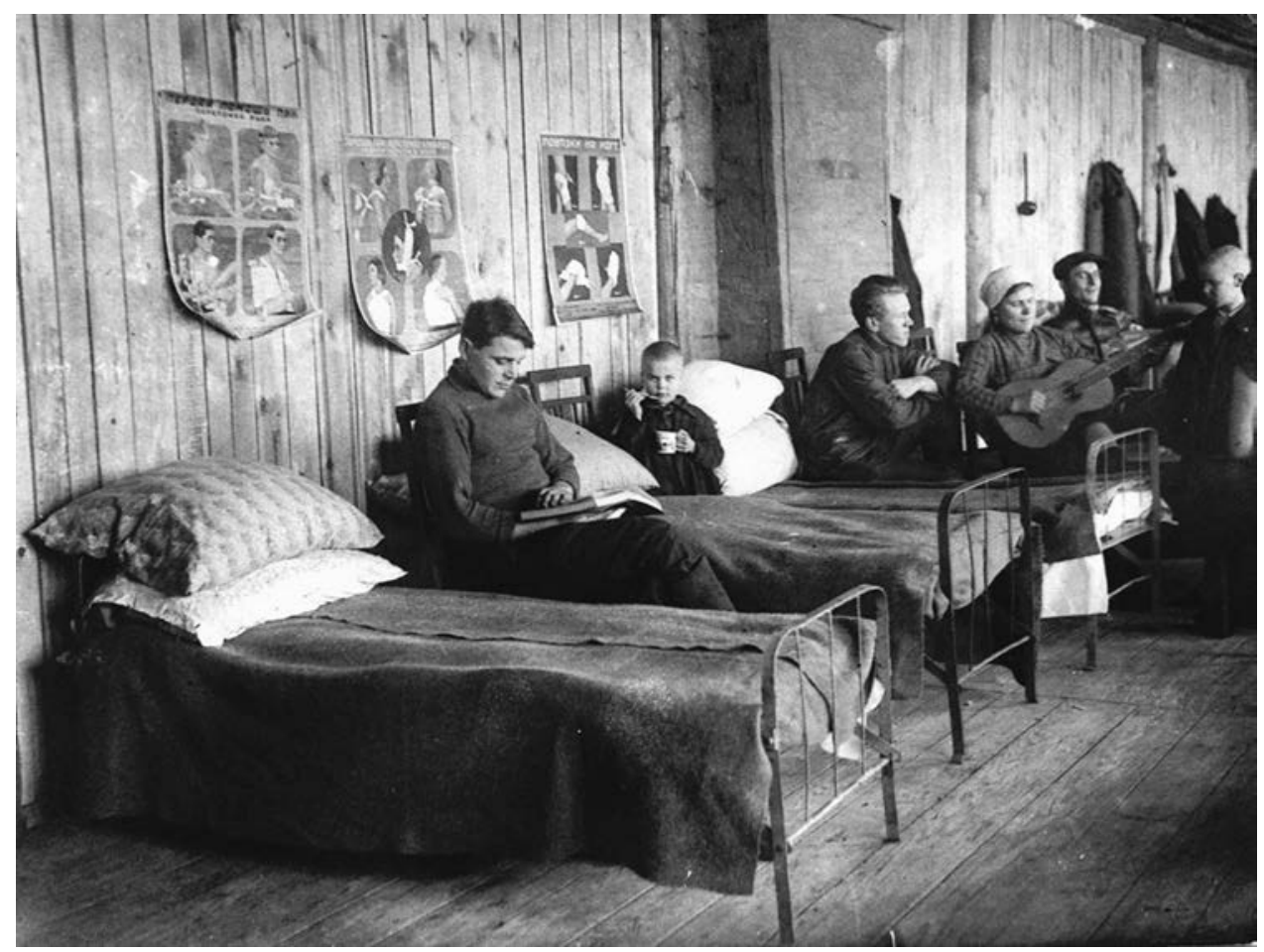

Figure 6.5. Family barracks, Magnitogorsk, Russia, c. 1931. Magnitogorskii kraevedcheskii muzei. 


\section{Internal Competition}

After site reconnaissance, a month-long internal design competition ensued. Chernyshev working for Giprogor, and May for Tsekombank, were ordered by the Magnitostroi administration to complete planning schemes for the city by November 25, 1930, less than a month into the future. ${ }^{52}$ May's team, used to working quickly, immediately began sketching alternatives in Magnitogorsk, continued on the train journey, and finished in Moscow. They purportedly converted one of their train compartments into a drafting room and "using the charcoal supplied as fuel for the samovar as pencils and drafting boards made of plywood pieces as a drawing base" produced a draft of a general plan. ${ }^{53}$ In another compartment colleagues typed up the explanatory texts for the project. The Tsekombank regional plan by the May team, dated November 1930, shows rectangular residential blocks originating at the southern end of the production zone and sweeping to the southeast (figure 6.6). The topographical model of this scheme explains the bowed shape of the housing region: it sits between the mine and industrial lake to the north, and a row of hills to the south, on the flattest land available close to the industrial zone (plate 14). The detailed site plan reveals that the Tsekombank scheme had much in common with the majority of the All-Union competition entries for Magnitogorsk, especially the "concentrated city planning" examples (figure 6.7). Repetitive residential communes fill in a wide band that wends its way in a southeasterly direction. May's standard residential building for Magnitogorsk is a zeilenbau of the Frankfurt type, a simple double exposure bar oriented along the north-south axis for maximal east-west insolation. In the bird's eye perspective, a drawing that uses perspectival drama to mask extreme regularity, blocks (kvartaly) for 8,000-10,000 residents extend into the distance in repeated rectangles; all buildings stand free, surrounded by green space (figure 6.8). ${ }^{54}$

Chernyshev was in the unenviable position of having to explain to his client that the project he had been working on for over a year was about to be snatched away. In a letter to the director of Giprogor, Chernyshev complained about chronic decisionmaking dysfunction on Magnitogorsk's fundamental planning questions. The very location of the city was still up for grabs. "We consider the choice of city's site to be the most critical task that stands before the State Commission," Chernyshev stressed. ${ }^{55}$ Almost two weeks after receipt of the letter, someone at Giprogor scribbled an elliptical note at the top- "what should we do about this question?"-that confirms that Chernyshev was plagued by indecision on all sides. Nevertheless, he and his Giprogor team pushed through and finished their version of the Magnitogorsk general plan. In every planning scheme he devised for Magnitogorsk, Chernyshev utilized a fan-shaped organizational strategy that resembles a quarter of Moscow's historically radial plan, with a trident of radiating blocks reaching out from a plaza at the factory gates (figure 6.9). 


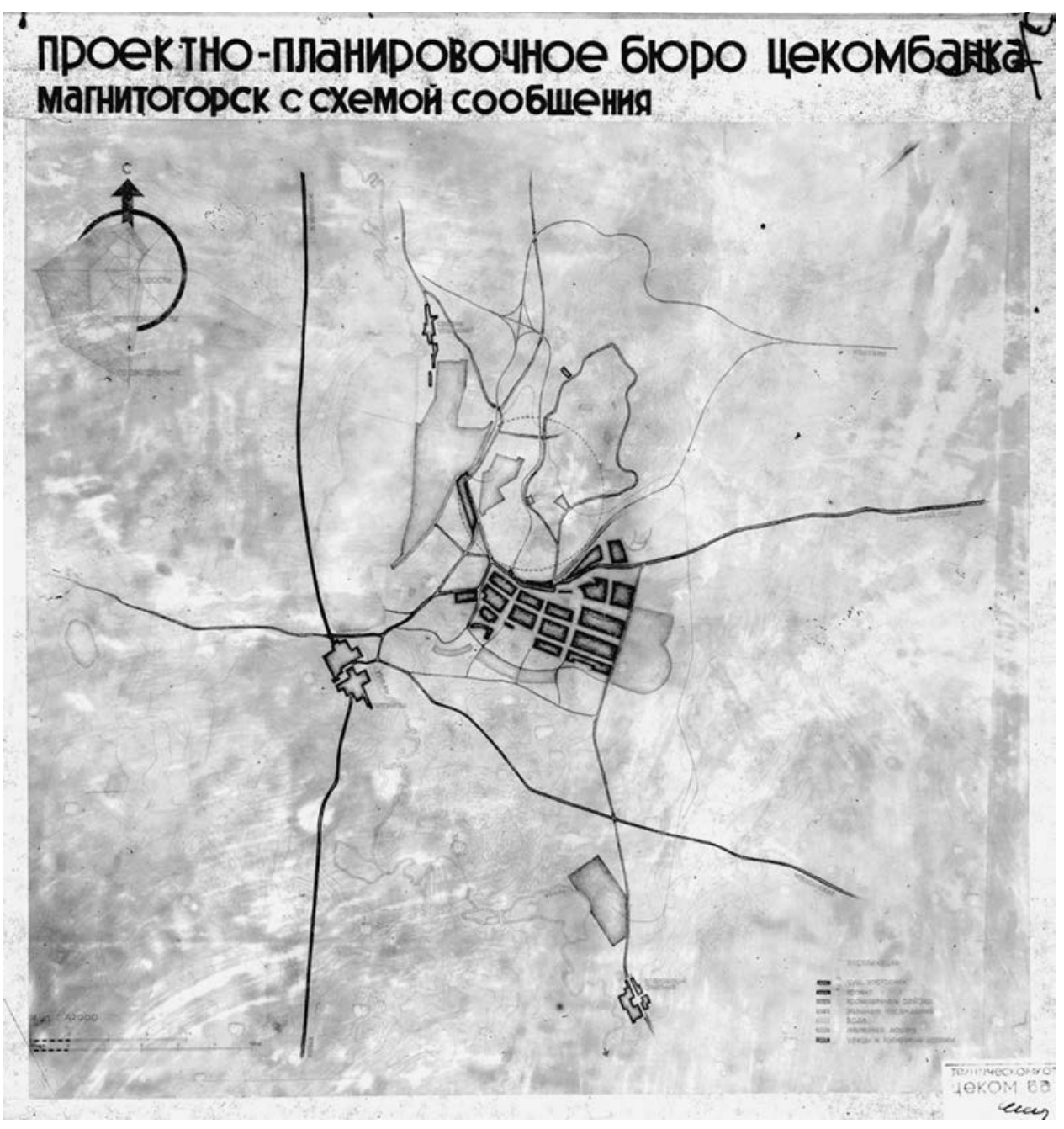

Figure 6.6. Left Bank socialist settlement scheme within the regional context, Magnitogorsk, Russia, November 1930. Rectangular residential blocks originate at the southern end of the production zone and sweep to the southeast. Planners: Tsekombank / Ernst May Brigade. MUAR, Negative 07569.

Experts, divided into two groups, met in Moscow in December 1930 to assess the May and Chernyshev schemes side by side. ${ }^{56}$ Among the eminent architects and planners gathered to select a scheme for Magnitogorsk was Ivanitskii, CIAM2 participant German Krasin, and E. V. Luganovskii, head of Tsekombank. The two groups disagreed on the most basic issue: on which riverbank to place the socialist city. They also disagreed over which of the two schemes to support (Ivanitskii's group claimed May's scheme superior, but the majority of experts favored Chernyshev). Over a two week stretch, various tables and reports comparing the plans were made, meetings convened, and debates held over siting, density, and architectural volume. May and Chernyshev were called before the commission numerous times to weigh in on topics such as how to distinguish the socialist from the capitalist city. 
Kirov District-the only portion of the

May Brigade socialist city to be built.

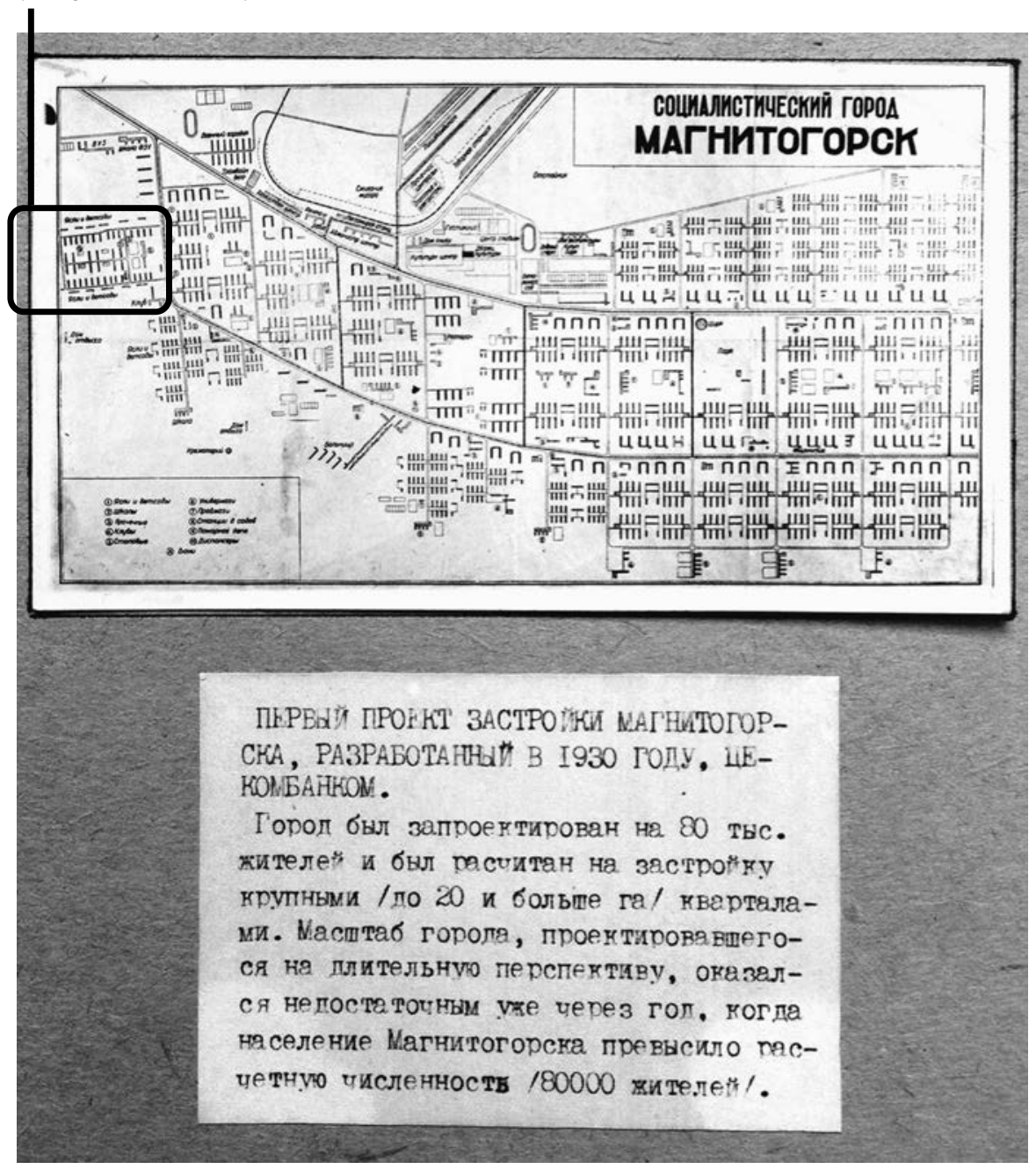

Figure 6.7. Left Bank socialist city, Magnitogorsk, Russia, 1930. The Kirov District, the only section of this scheme that was built, is located on the upper left-hand corner of the site plan. Planners: Tsekombank / Ernst May Brigade. Magnitogorskii kraevedcheskii muzei. Diagram by the author.

As May sat among the discussants, reliant on spot translation, he found his project maligned as a stereotypical example of capitalist urbanism. "But how do you understand capitalist city? Have you not read my explanatory text?" he asked exasperatedly through his interpreter. ${ }^{57}$ To May, writing later in 1931, the difference between the two was straightforward.

The capitalist city has developed concentrically around the marketplace, and the rich, the middle classes, and the proletarians live in clearly separated districts of their own. This differentiation of class structure is recognizable from 
afar and defines the capitalist city's particular character and form. The city in the USSR knows only one class, the class of working people. Therefore, apart from the aforementioned requirement of locating people as close as possible to their respective places of work, the task consists of the equal distribution of all communal functions, for everybody's equal enjoyment. ${ }^{58}$

Chernyshev's project showed three parks for each lobe of his city; May's consolidated the citywide Park of Leisure and Culture in a single location. Which park configuration better represented the goals of socialist urbanism? A 4-2 vote on this point gave May the advantage, but again, no definitive consensus was reached. ${ }^{59}$

On December 10, 1930, May was declared the winner of the planning marathon, purportedly because his project was "worked out to a greater degree of detail, and because he has more organizational experience directing city construction." ${ }^{\circ}$ In other words, the plan was good enough, and most important New Frankfurt, despite the taint of capitalism, was the ultimate proof that May could deliver an economical project quickly. ${ }^{61}$ The May Brigade's first phase of work in 1931 was to

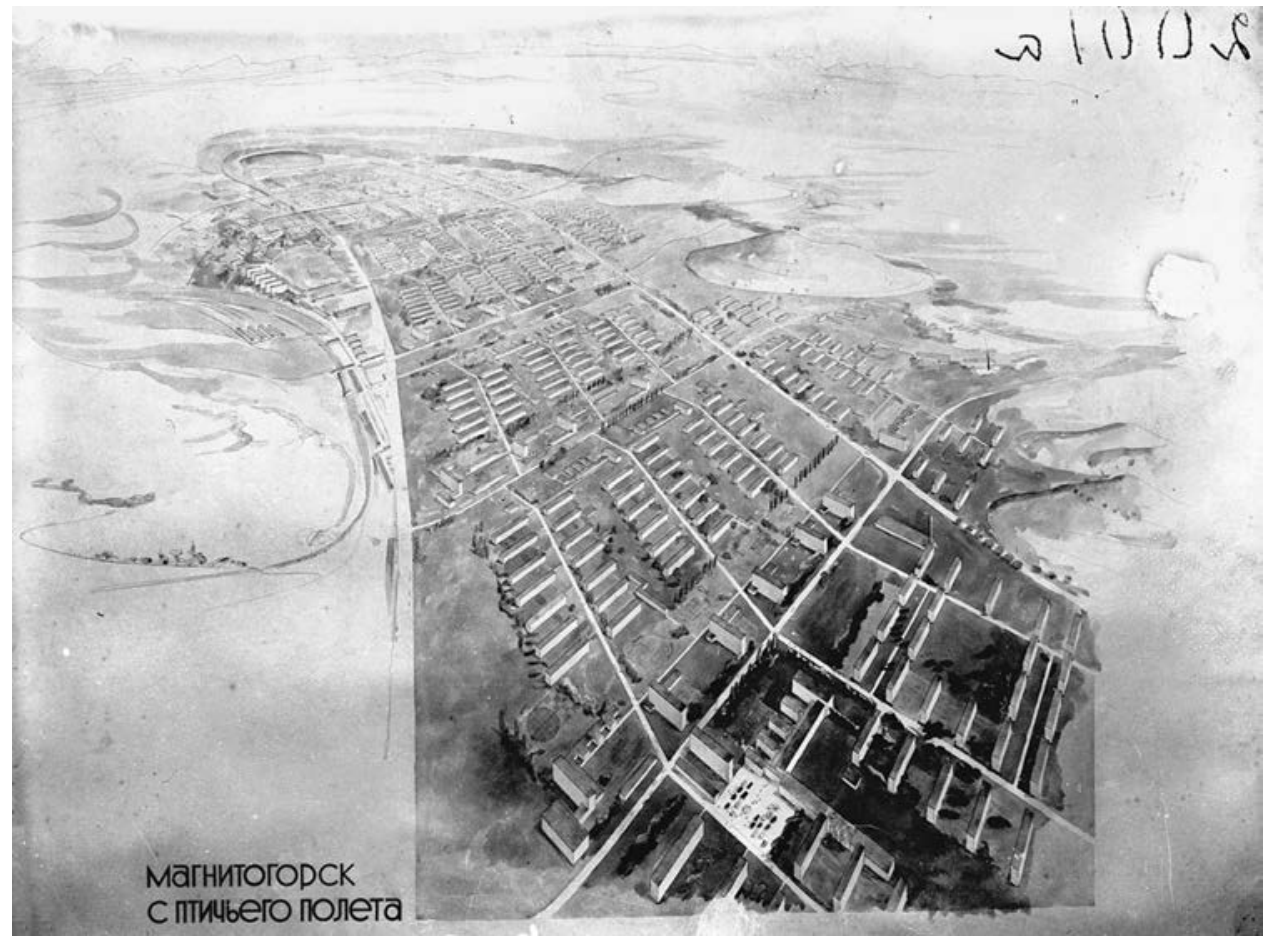

Figure 6.8. “Bird's Eye View," Left Bank socialist city, Magnitogorsk, Russia, 1930. Repeated rectangular blocks (kvartaly) for 8,000-10,000 residents extend into the distance. Planners: Tsekombank / Ernst May Brigade. MUAR, Negative VII-576. 


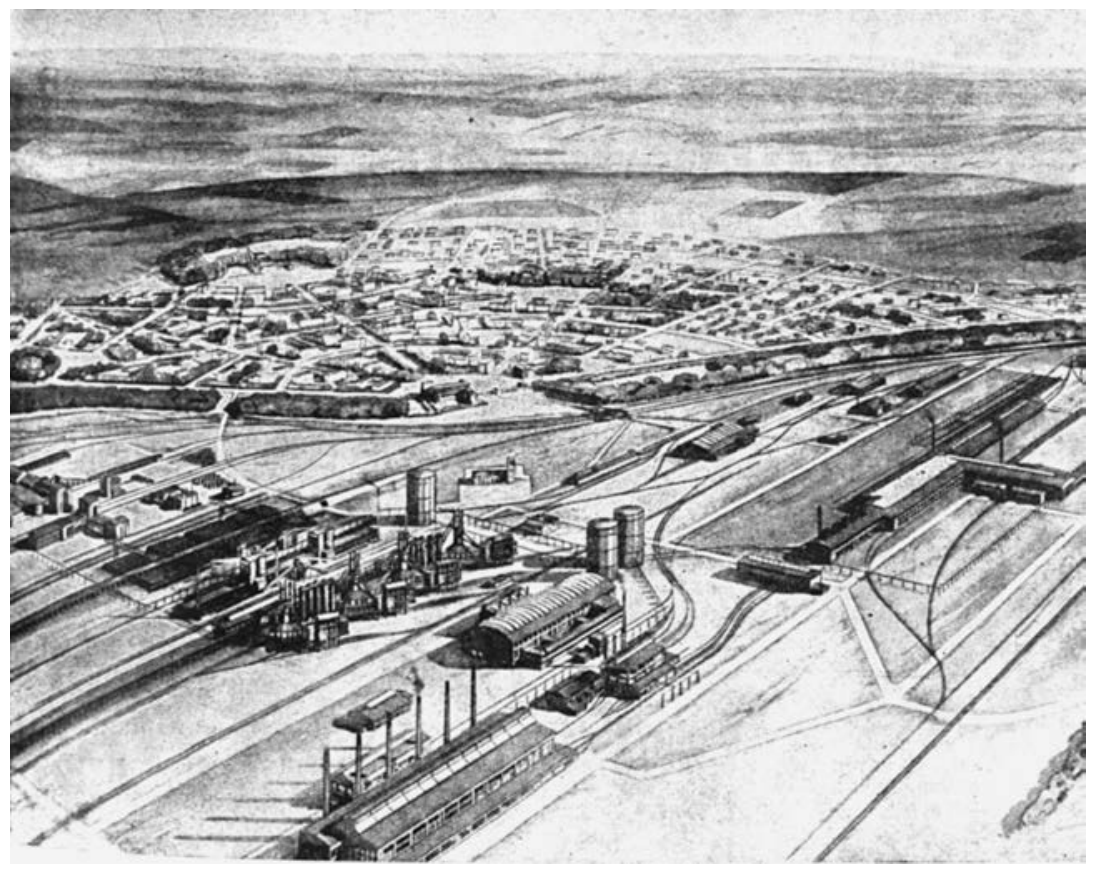

Figure 6.9. Widely published perspective of Chernyshev's fan-shaped city plan, Magnitogorsk, Russia, 1930. Planners: Giprogor / Sergei Chernyshev. M. Il'in, Rasskaz o velikom plane, 3rd ed. (Moscow: Ogiz-Molodaia gvardiia, 1931), 101.

design one test case kvartal (residential superblock) for 15,000 people to include a canteen, workers' club, stores, preschools, kindergartens, public baths, garages, fire stations, and ambulance facility, a factory bakery, open market, and other communal structures. In small consolation to the second-place architect, May was directed to use "a few solutions from Chernyshev's project," like a more westerly location for the Park of Leisure and Culture. ${ }^{62}$

Chernyshev may have lost in the short term, but he proved an astute player of the long game. From 1934 to 1941, he served as the Chief Architect of Moscow. Along with Vladimir Semenov, another prerevolutionary architect who waited out the avant-garde era, Chernyshev authored the 1935 General Plan for Moscow, an urban design-concentric, as was his penchant-that that was arguably more influential on Stalinist city planning than was May's Magnitogorsk intervention. ${ }^{63}$

\section{Shifting Territories}

As Chernyshev's letter of complaint to Giprogor suggested, managerial indecision plagued the Magnitogorsk city-building project. Most gravely, administrators could 
not agree where the city should be built. Convenience and cost savings determined the original left bank siting: housing proximate to the factory would result in less capital outlay for bridges over the Ural River to the right bank. The left bank location was justified further by a decade-old wind study that indicated a southwesterly wind pattern at the site. A month after the left bank-sited All-Union Design Competition was published, a commission of local construction administrators raised the possibility of building the city on the right bank of the Ural River, a change of tactic prompted by living experience. ${ }^{64}$ Once factory construction began, administrators and residents alike noticed that industrial smoke blew most frequently in a southeasterly direction from the factory directly into the proposed residential site, proving the old wind study patently incorrect. ${ }^{65}$

With a new planning team at the helm, and despite the fact that all residential and administrative buildings were already located on the left bank, the question of the proper location for Magnitogorsk was posed anew. The most intense period of debate occurred between November 1930 and the end of May 1931. During those seven months the officially designated location of the city shifted from the left to the right bank and back seven times (plate 15). ${ }^{66}$ In countless meetings on the topic in both Magnitogorsk and Moscow three options were considered: 1) continue to build the city on the left bank; 2) move all new city construction to the right bank; 3) follow a hybrid path and immediately construct a population-limited worker settlement (20,000-30,000 residents) on the left bank, while siting the future city on the right bank. ${ }^{67}$

In the absence of a clear locational directive, May's Tsekombank design team produced both left and right bank schemes for the city (figure 6.10). ${ }^{68}$ Many of the architectural and planning issues that they resolved in this early period were, in fact, site-agnostic. Sitting in their rolling office on a rail spur outside of Novosibirsk, May's team typed out an explanatory text for their Magnitogorsk design that mentioned the siting briefly (at that point the primary scheme was for the left bank), but that more thoroughly concerned the housing types, construction technologies, and communal amenities for the new workers' settlement. The basic building block of the socialist city was the kvartal for 10,000-15,000 people. "The entire city will consist of the sum of these kvartals," and include clubs, canteens, a cinema, schools for children of a range of ages, shops, laundries, baths, ambulance service, and sports fields in addition to housing. ${ }^{69}$ May's kvartal matches almost exactly Sabsovich's definition of the zhilkombinat requested in the All-Union competition, although it accommodates over five times the population. In each case, a single well-designed block type is repeated to reach the city's population goal, a strategy that assumes standardization not only of housing types but also urban units.

May and his brigade preferred the right bank scheme for Magnitogorsk for all of the reasons that it was eventually adopted in the postwar period. He explained that "it was quite clear to us that the right bank of the river, thanks to its uniform 


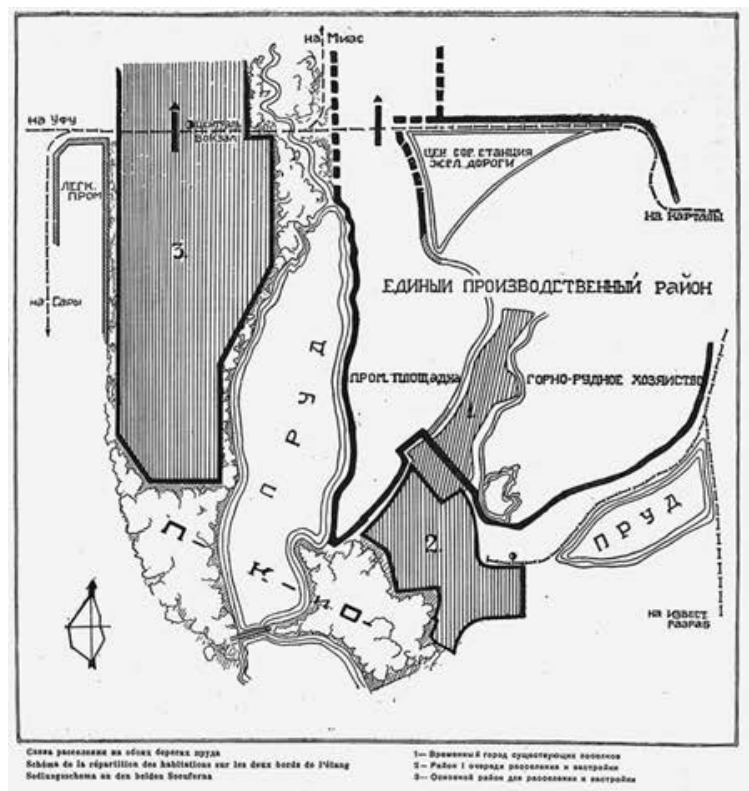

\section{Right Bank Variant}

1. Temporary existing settlement

2. Region for the first phase of development and construction.

3. Primary region for development and construction.

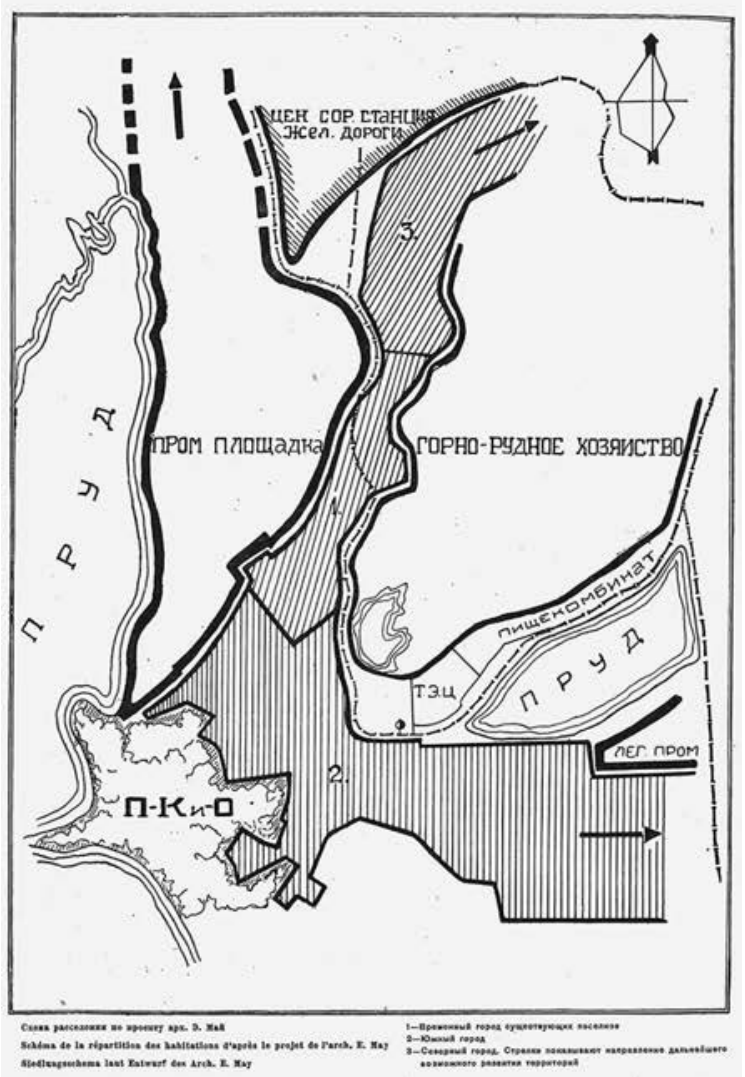

\section{Left Bank Variant}

1. Temporary existing settlement

2. South city

3. North city. Arrows indicate the direction of growth of the future city.

Figure 6.10. Left Bank (top) and Right Bank (bottom) variants for the socialist settlement, Magnitogorsk, Russia, 1933. Planners: Standartgorproekt / Ernst May Brigade. Sovetskaia arkhitektura, no. 3 (1933). Diagram by the author. 
slope, is preferable for the organization of a residential town than the more difficult site located close to the factory on the left bank. We also have no doubt that the right bank is an extremely convenient site for the construction of the railway line that will connect the new city to the network of magistrals." ${ }^{70}$ In addition to right bank's gentle topography and convenient access to rail lines and future highways, the location afforded both industrial and residential sectors room to expand without conflict, and prevailing southeasterly winds would blow industrial smoke away from right bank housing. May conceded, however, that the socialist city had to be built on the left bank for three reasons out of his control. First, the dammed and widened Ural River created a two-kilometer distance between the factory and the nearest possible right bank settlement. Specialists determined that at least two bridges would be needed to connect the riverbanks, a prospect that was fiscally improbable in the near future. Second, left bank construction "provided a pedestrian connection between the residential and industrial areas for a very large part of the industrial workers and miners who thus could live without mechanical transport." ${ }^{71}$ The workers' ability to walk from left bank housing to the factory deferred investment in costly transportation infrastructure. Lastly, a sizable number of temporary structures, roads, electrical wires, and other infrastructure already had been installed on the left bank. Those settlements had to be incorporated into the general plan so as not to squander the investment already expended. When May gave these justifications for a left bank settlement in a 1932 article for Sovetskaia arkbitektura, almost a year had passed since the Sovnarkom of the Russian Republic issued Protokol no. 405 in favor of the left. A definitive resolution by STO in August 1932 closed debate, and May was obliged to design a left bank general plan for Magnitogorsk that ran counter to his best planning instincts.

May's tactical retreat at the end of 1932 had much to do with his diminishing status in the USSR. In September 1931, the Tsekombank planning office merged with Gosproekt no. 2 (a planning office of the Vesenkha of the Russian Republic) to create Standartgorproekt. May was designated chief engineer of the new design organization and granted extraordinary powers in his position, but his upper echelon location in the Soviet hierarchy was short-lived. ${ }^{72}$ In Magnitogorsk, 80 percent of residential construction funding for 1931 (6.5 million of the 8 million allocated) was siphoned away from housing to build the factory. Union-wide, the astronomical targets set for new housing in 1932 were only 10 percent fulfilled. ${ }^{73}$ May was held personally accountable for these grim statistics as head of Standartgorproekt, the organization nominally responsible for meeting residential construction targets.

When May was granted an audience with Commissar of Heavy Industry Sergo Ordzhonikidze in the fall of 1932, he tried to broach the subject of the city's location in an amusing manner by presenting Ordzhonikidze a cardboard clock with "left bank" and "right bank" printed on opposing sides of the circle. The US engineer Zara Witkin, who befriended May in Moscow, recounted the interaction. When Ordzhonikidze asked May “on which side of the river is the housing of 
Magnitogorsk to be?" May asked, "what month is this?" "Nettled, the commissar answered testily, 'March!' 'Ah,' said May, drawing the [clock] from his portfolio and turning its face to the commissar. Silently, he swung the arm around the dial ... 'This month the housing will be on the left bank of the river, commissar!' he said." 74 "I had hoped to gaze into a smiling face," May wrote later of the ill-fated meeting. "Instead, O. looked at me with an earnest expression, put the clock face down on the table and finally told me that a decision would be made before long." 75 May later cited this encounter as the moment when he realized that he would have to leave the USSR.

The Magnitogorsk general plan completed by the May Brigade in 1933, as employees of Standartgorproekt on their way out the door, retained a left bank design (figure 6.11). This version shows two residential areas (the dark blocks) that flank the production area to the north and southeast. The northern sector is located to benefit from rail adjacency and proximity to the open steppe for future expansion northward. The southern sector is squeezed between the factory, the lake, and the mountains in the location utilized in the All-Union competition of 1929 and the May Brigade's first draft plan. The right bank of the Ural River is cut off from the drawing completely, as if to foreclose any future discussion on the matter.

This final published general plan is an almost unrecognizable sibling to the hyper-detailed plans of May's standard oeuvre, in which each individual zeilenbau building is carefully inked-in, no matter the drawing's scale. The Magnitogorsk general plan is a retreat from specificity to ambiguity. How is the abutting relationship between residential and industrial sectors handled? How are the kvartals organized? What are the residential building types? None of these questions is answered in this plan, which provides only a vague blueprint for future city-builders. May's accompanying text suggests that in the numbers-obsessed early Soviet context, withholding detail was his planning team's final subversive act:

A far-sighted planned economy will admit the possibility that even the best organization of urban construction does not have at its disposal prophets capable of anticipating change with an accuracy up to 90 percent. Therefore, the master plan cannot be viewed as a complete, accurate picture of the city's development for ten or even twenty years ahead. It is rather a "desirable" plan; perhaps it would be more accurate to compare it to the plan of an army on the march. All military units and all types of weapons are distributed in certain places to ensure the attainment of a specific military goal. However, when the plan is launched a certain role belongs to the adversary who, through his movements, requires the commander to adapt his plan to the requirements of reality.

As applied to urban construction, this means that the master plan cannot and should not represent a completely frozen condition but should, on the contrary, possess considerable elasticity, allowing it to be coordinated continuously with changing living conditions. ${ }^{76}$ 


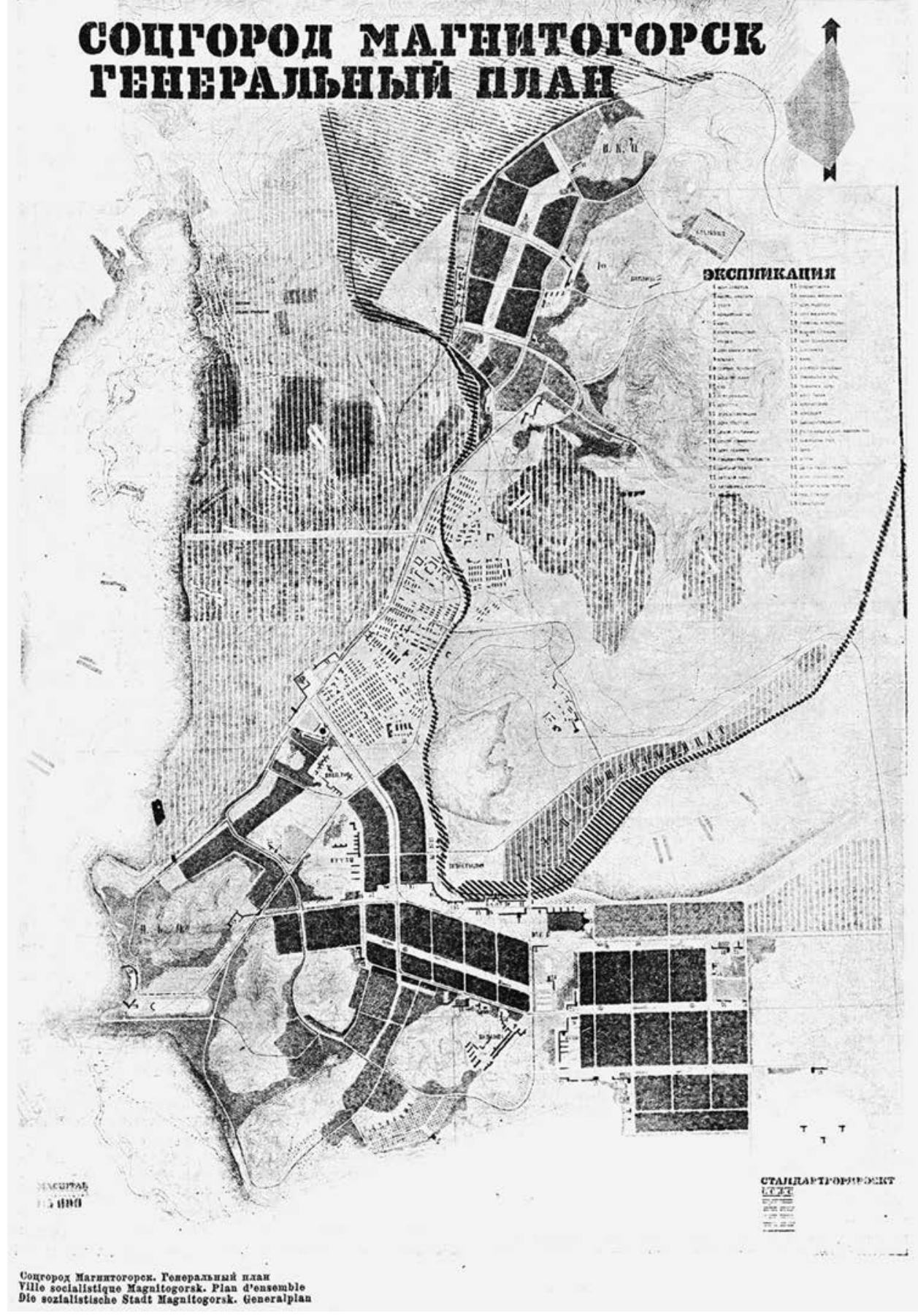

Figure 6.11. Sotsgorod General Plan, Magnitogorsk, Russia, 1933. Planners: Standartgorproekt / Ernst May Brigade. Ernst May, "K proekty general'nogo plana Magnitorgoska,” Sovetskaia arkhitektura, May-June (1933): 19. 
May's explanation for the plan's indeterminacy could be read as defensive. After all, the planner arrived in Magnitogorsk guns blazing (to continue his military metaphor), ready to install a rational Frankfurt-like plan with speed and efficiency. The so-called requirements of reality in the increasingly bureaucratic Soviet Union forced him to acknowledge that the project was out of his hands, and that he had accomplished little. Conflicting ideas about the proper form and location of the Magnitogorsk sotsgorod caused almost complete paralysis; the master plan could not be drawn when so many fundamental issues remained unresolved. May's vague plan is a white flag of surrender, a final concession to the complexity of Soviet conditions.

\section{Frankfurt on the Steppe}

The material legacy of the May Brigade in Magnitogorsk is found in a small section of the 1932 master plan constructed between 1931 and 1934 that still stands today. Called variously the Kirov District, the Socialist City, or Kvartal no. 1, this block that sits south of the factory on the left bank and is composed of freestanding housing bars aligned in parallel north-south rows: zeilenbau on the Soviet steppe (figure 6.12). As constructed, the neighborhood is an architectural hybrid. Pionerskaia Street, the central east-west axis of the plan, is flanked by six pairs of four-story buildings designed by Gosproekt and constructed before the May Brigade completed their housing designs. The Gosproekt buildings are 70-meterlong, 12-meter-wide brick apartment houses with shallow-hipped roofs, large windows, and balconies. In their original state, the spatially generous units ranged from three to five rooms, and each enjoyed its own kitchen, bath, and balcony. Three-story "sectional houses" (sektsionnye doma), designed by the May Brigade, sit at the north and south edges of the block (plate 16). Although the foreign architects designed a handful of housing types for Magnitogorsk, the majority constructed are the INKO-A type: 72-meter-long, 11.5-meter-wide row buildings (plates 17-18). The INKO-A is made up of seven standard ten-meter "sections" placed side to side, each of which holds a switchback stair and two two-room, double-exposure units per floor block. These modest units were designed without kitchens, on the architects' assumption of communal food provision within the kvartal, although the designers noted that one room could be converted to a kitchen later if the residents so desired. ${ }^{77}$ The stucco exteriors of the INKO-A houses are devoid of ornamentation, but large windows and regular balconies provide volumetric relief on the simple, brightly painted facades. Open space between the east-west facades of the sectional house is at a width of 3-3.5 times the height of the buildings and was intended for passive recreation, gardens, storage sheds for fuel and preserves, and small communal buildings. 


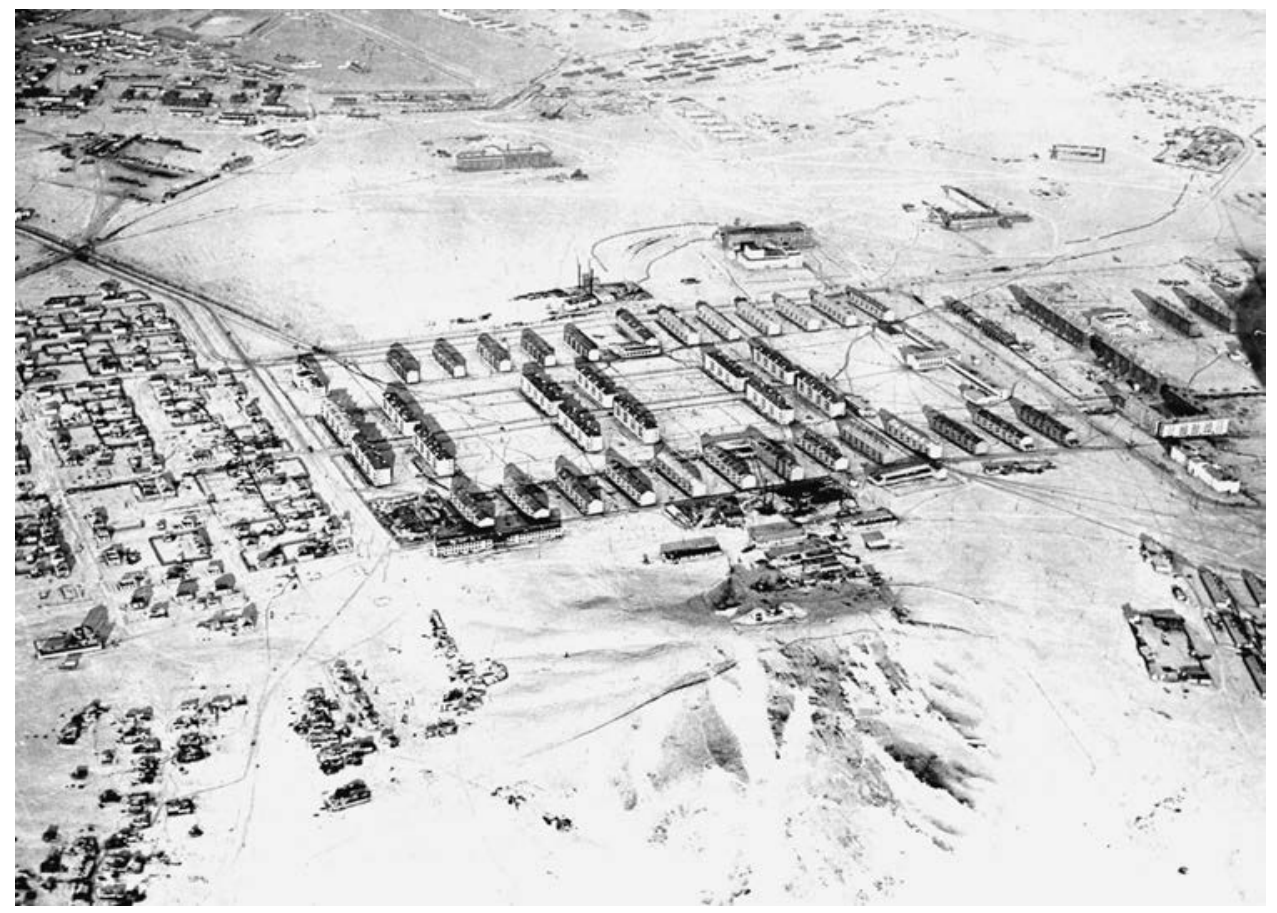

Figure 6.12. Kirov District after construction, Magnitogorsk, Russia, 1933-34. Architects / Planners: Gosproekt / Standartgorproekt / Ernst May Brigade. Magnitogorskii kraevedcheskii muzei.

The north-south orientation of the Kirov District's buildings, the green space between them, their narrow depth, and their austere character ally this project with May's New Frankfurt, especially the last phase at Praunheim. Despite the involvement of two different architectural teams-Gosproekt led by designers from within the Soviet system, and Standartgorproekt led by designers from a socialist municipality in the capitalist West-the overall scale and exterior character of the residential buildings in the Kirov District are markedly similar, making it all the more difficult to characterize these buildings as belonging to a specific economic or social system. Do any of these buildings communicate their affiliation to a specific ideology, as commentators on both sides claimed they did? Can a building look capitalist or socialist?

May broached the subject of socialist architectural expression when he wrote about the Magnitogorsk project for the Soviet press. "In view of the fact that the first socialist state in the world is relatively young, the architectural design of a socialist city has no firmly established image. We know only one thing: that in appearance, the socialist city will differ significantly from obsolete capitalist cities. New completely 'recrystallized' forms of human society should create an architectural image corresponding to a classless state." ${ }^{78}$ Lest the reader of Sovetskaia arkhitektura be led to believe that May's evocation of "image" signaled a 
return to architectural design from the outside in, May clarified that it is the programmatic attributes of socialist housing that must determine its appearance. He explained:

The basic requirement of planning and building a socialist city is to create for the entire population equally favorable living conditions with respect to the internal organization of the dwelling, its lighting, ventilation, social and cultural services, and communication amenities. The most radical implementation of this basic requirement is the "linear" (strochnaia) construction, which in recent years has increasingly spread in the modern architecture of Western Europe. We considered the shortcomings associated with the monotony of parallel blocks oriented at a slight angle to the north-south direction. But, in rejecting paper eclecticism, we give paramount importance, first and foremost, to providing the most essential elements without compromise. ${ }^{79}$

May justified the rational site plan and austere exterior expression at the Kirov District as the logical outcome of designing for a classless society. He argued that the point is not what the housing looks like but how it functions, an explanation already well practiced by Constructivist practitioners like Moisei Ginzburg. If the quintessential needs of each resident are met-light, fresh air, social, cultural, and technological amenities - then the architecture is suitably socialist. May acknowledged the critique of experiential monotony among the zeilenbauen at New Frankfurt and in his plan for the Kirov District, but he asserted that the careful siting of communal buildings at variegated heights and orientation "revitalized the architectural design of space" by providing massing contrast, and further, that "using the features of the terrain, the plan constantly seeks the most economical way to increase the impact of individual structures." 80 The INKO-A buildings on the southern edge of the kvartal climb a slight rise and stagger in elevation as they do so, rendering the standardized sections more lively, as May suggested.

The Moscow-based architect Dmitrii Shibaev wrote an immediate rebuttal to May's article in Sovetskaia arkhitektura, critiquing the architecture of Magnitogorsk's Kirov District and questioning whether a nonsocialist designer could properly address the needs of the Soviet populace. Shibaev used May's support for nonhierarchical, functional architecture against him. "The author [May] supports the planning of buildings in rows, stating that most progressive Western architects utilize it. This is despite the monotony of these structures, which they are compelled to put up in the name of advanced functional architecture. Such housing construction, which is natural for capitalist cities pursuing the goal of exploiting working people, creates a diminished quality of life for the individual due to the linear construction of such 'barracks." 81 Shibaev accused the INKO-A housing rows, although designed specifically for Magnitogorsk, of being Frankfurt zeilenbauen in disguise. Shibaev also argued against industrially standardized housing 
construction if the process resulted in long uniform lines of buildings that favored the needs of machines over humans. "For the convenience of the crane," Shibaev admonished May, "man is forced to live 'between the lines' that overwhelm his psyche." ${ }^{82}$ Functionalism was no excuse for monotony which, to Shibaev, resulted in architecture that snuffed out the proletarian spirit. A July 14, 1932 resolution by Mossovet (the municipal administration of Moscow) stated that the preferred site planning strategy for Soviet housing going forward would be the perimeter block lined with "individual" variegated architecture. In no case would "the use of boring, monotonous facades" be permitted, Shibaev reported.

Despite their architectural similarities, the Kirov District differed from New Frankfurt in one significant respect: its modest impact. In Frankfurt, May oversaw the construction of 15,000 units in five years. ${ }^{83}$ The May Brigade's contribution in Magnitogorsk, on the other hand, was approximately 1,050 units in 25 residential buildings, and the Kirov District as a whole accommodated just 4 percent of Magnitogorsk's population in November $1932 .{ }^{84}$ While the neighborhood was planned to offer ample communal infrastructure in addition to housing, little was actually built. In 1933, one canteen and one food products store, a kindergarten for 160 children, a school for 640 students, and boiler room (kotel'naia) were completed, providing less than half of the promised services. ${ }^{85}$

At the end of 1933, Ernst May and most of his architectural brigade left the USSR. Their three-year design consultancy had limited material impact in Magnitogorsk. For all of the evocative drawings and models generated during their tenure as designers for the model steel city, just one small neighborhood was constructed based on their designs. This is not to say that their efforts were without long-term effect. In the years after the Kirov District was constructed on the left bank, state and local administrations finally conceded that the right bank was the best site for future residential growth. The Kirov District became detritus of an earlier era of the city, an island of the everyday in the heavily industrial territory of Magnitogorsk's left bank. May's urban planning position finally won the day, which meant that his architectural legacy in the city was left to languish.

Of the three sites linked in this narrative, Magnitogorsk was burdened with the highest expectations. Because of the city's importance to Soviet industrialization and the spotlight trained on it through pervasive publicity, the architects and physical planners who cycled through the design project from 1929 to 1932 were under pressure to satisfy a host of conflicting goals in their work. The designers were expected, first, to invent unprecedented urban forms based on theories of socialist city making unfolding in real time. Those who actually set foot in Magnitogorsk then had to modify their inventions to grapple with the complexities of a site that thwarted installation of prevailing urban theory at every turn. Because Magnitogorsk was a project in which design tasks and decisions came from the top down, both Chernyshev and May, the longest serving designers for the city, were 
heavily monitored by officials in Moscow and Magnitogorsk, and had scarce time or resources to engage in hands-on praxis to solve problems presented by industry and nature. They found themselves between a mountain of iron ore and a hard place, as it were.

Ernst May arrived in Magnitogorsk having proven his mettle through the delivery of workforce housing in Frankfurt am Main, and in both Germany and the USSR, May worked for socialist clients whose design tasks he embraced. In both contexts, he designed housing that shared architectural arrangement, form, and character. These narrow, spare, multiunit apartment buildings, placed in regular rows on a superblock, constituted the archetypal socialist housing solution, argued May. Homogeneity at the housing unit, building, and site planning scales visually communicated a flattening of class structure. But, most important, each citizen was provided "the most essential elements without compromise," which included access to natural light and ventilation inside the unit, and social, cultural, and communication amenities within close proximity to it. ${ }^{86}$ Cooking, eating, recreating were deemed communal activities, and were extracted from the domestic unit and cast into the wider territory that, whether dubbed a zhilkombinat or kvartal, constituted an inherently socialist space. Once the design solution was resolved, May claimed, it could be replicated infinitely, ensuring fair and equal living conditions for all residents. The instaurational text of the All-Union competition briefMay's basic rules for operating in the Soviet condition-did result in constructed space, albeit significantly more modest in scale than projected or desired by the brief's drafters.

What, then, were the critical differences between the two scenarios, and why, in the end, was May unable to pull off a repeat of his Frankfurt success in Magnitogorsk or any other Soviet city on which he worked? There are myriad reasons why May's built footprint in the Soviet Union fell short, but five contextual conditions were irredeemable: project scope (continental), client-planner relationship (shifting, out of view), location (remote), program (much exceeding housing), and client priorities (industry first, all else afterward).

First, there was the matter of scope. May's work in Frankfurt was municipally scaled. The architects on his team designed for their local context and any bureaucratic or topographic conflicts that arose were addressed immediately. In the USSR, May's territory of responsibility was the entire Soviet Union. Magnitogorsk was just one project among many that May and his brigade tackled as planning consultants to the Soviet government. Their efforts were divided among many locations that were geographically, experientially, and culturally remote for the mostly German design teams who were spread too thin. Second, the client-planner relationship differed. As long as housing targets were met, May’s client in Frankfurt, Mayor Landmann, did not meddle in questions of architectural and urban theory. Decentralization, heliotropism, functionalism, and industrialized construction were strategies proposed and ultimately implemented by May in Frankfurt. In the Soviet Union, May's client 
was a diffuse, multiscalar, mercurial entity, and he was a just a planner. His tasks were limited to solving design problems and taking ultimate responsibility for meeting housing targets. By 1930, the urban and social theory to be installed or avoided in a project like Magnitogorsk was dictated by the highest levels of Soviet power and May disregarded these directives at his own peril. Third, Magnitogorsk-and each city that the May team was tasked to design—was radically remote from existing infrastructure. It was not a blank site, but it was difficult to provision, staff, and ultimately build. Fourth, there was the question of the program. In designing the siedlungen in Frankfurt, May solved a housing problem. For his socialist municipal client, he included limited ancillary services like libraries and schools within the residential precinct at his own discretion. In Magnitogorsk, the program was much broader and included housing, social and commercial infrastructure, education, recreation, transportation, communications and hygienic infrastructure, and interface with industrial planning. Given the administrative dysfunction rampant in all of those realms in Magnitogorsk, any high-level attempt to solve them systemically was bound to fail.

Lastly, and perhaps most critically, with heavy industrial construction as his client's top priority, soft construction like the Kirov District was sorely undervalued and subsequently underfunded. Within the confines of Frankfurt's municipal socialism, and as director of municipal planning, May had complete juridical power over planning and architectural decisions. His budget to construct the siedlungen was tight, but a fixed capital funding cap was virtually the only limit with which he was faced. In Magnitogorsk, just 20 percent of funding allocated for housing construction in Magnitogorsk during May's tenure actually went to building housing. ${ }^{87}$ Teleological planning permitted the abstract shift of numbers, and physical shift of building materials, from one site to another to ensure the success of the banner project: the factory. In short, May had to engage in total planning with a tiny budget and limited bureaucratic support. The gap between May's professional status in Frankfurt and the Soviet Union was ultimately unbridgeable.

Although it was beset with its own significant setbacks and missteps, the Magnitogorsk factory construction project did continue apace during the official dithering about the location and constitution of the socialist city. ${ }^{88}$ The impossible industrial targets set by Moscow for Magnitostroi brought about a cognitive and logistical separation between production and reproduction, which proved devastating for the workers in the city. Using the design tool of architectural standardization, the Kharkiv Tractor Factory and its sotsgorod would be able to move interdependently, in lockstep. 